\title{
Archaeology in the Adriatic. From the Dawn to the Sunset of Communist Ideologies
}

\author{
Elisa Cella ${ }^{1}$, Maja Gori ${ }^{2}$, Alessandro Pintucci ${ }^{34}$ \\ ${ }^{1}$ Museo Civico Etrusco Romano di Trevignano Romano, ${ }^{2}$ University of Heidelberg, ${ }^{3}$ Sapienza \\ University of Rome
}

\begin{abstract}
By adopting historical and sociological approaches to archaeology, this paper focuses on the development of archaeology in Albania and Yugoslavia and their relation first to fascism and then to communism and socialist regimes. Identity issues based on archaeological discourse in former Yugoslavia and Albania are often perceived and regarded by western scholarship as extreme distortions and abuses of archaeological practice to promote nationalism. By providing a comparative and diachronic perspective, this paper aims to demonstrate that the way in which a society relates to its past is a complex phenomenon, and that political uses of archaeology in the western Balkans cannot be associated entirely with socialist regimes and communist ideologies. It is argued that different uses of archaeology are the product of a complex interaction between the development of archaeological discipline and historical, social and cultural trajectories.
\end{abstract}

Keywords: Albania, Yugoslavia, Nationalism, Fascism, Communism

\section{Introduction}

The study of archaeology in its social, political and economic context gathered increasing attention from the 1980s onwards, when authors such as Trigger (1989) and Hodder (1991; Hodder \& Hutson 2003) used historical and sociological approaches to demonstrate that archaeology as a discipline is embedded in a specific cultural and historical milieu, and that it must be understood within its social, political and cultural contexts. Following the dissolution of Yugoslavia and the Soviet Union, and the resulting rise of a plethora of new nation states, the debate became more articulated, as scholars exhibited a renewed interest in the study of archaeology's relationship with politics and identity construction (see e. g. Kohl \& Fawcett 1995; Diaz-Andreu \& Champion 1996; Meskell 1998). The main focus was on the western and central parts of Europe and on the Middle East, and few publications focused specifically on the relationship between archaeology, cultural history and identity building in south-eastern Europe (one exception is Kaiser 1995). In the literature devoted to archaeology and identity published in the 1990s, in discussing archaeology and its relation of past to present identities authors frequently mention Yugoslavia and the Yugoslav conflict as an emblematic example for archaeology and its relation to identity issues, mainly in relation to nationalist discourses, ethnicity, and xenophobia, but never go into depth on Yugoslavia itself (for example in Graves-Brown et al. 1996). On the other hand, Albania is often taken as paradigmatic example for discussing the use of archaeology in national identity building in connection to dictatorship (as in Galaty \& Watkinson 2004). In both cases misuses of archaeology have been connected to communism and socialist regimes. In socialist countries, indeed, great importance has been placed on the internal integrity and

${ }^{4}$ All authors have contributed equally to the ideas at the basis of this work. Individual author's contribution is specified at the end of each paragraph (EC/MG/AP). 
historical continuity of the ethnos, and ethnic identity was perceived as formed by cultural and linguistic components which constituted the 'inner integrity' of a group's identity. These elements were emphasized as they become the basis of the archaeological discourse in Eastern Europe (Diaz-Andreou \& Champion 1996: 5). Hobsbawm has argued that

"Marxist movements and states have tended to become national not only in form but in substance, i.e. nationalists" (Hobsbawm 1977: 13).

Often identity issues based on archaeological discourse in former Yugoslavia and Albania are perceived and uncritically regarded by western scholarship as extreme distortions and abuses of archaeological practice to promote nationalism. Hamilakis (1996: 976) has however pointed out how in the attempt to condemn an ideology of exclusion, new boundaries are reproduced by constructing the knowing subject as the holder of objectified knowledge who condemns the irrational 'other', 'orientalizing' thus the producers and the followers of nationalist myths set against the rational and scientific West.

By adopting a comparative and diachronic perspective, this paper aims to demonstrate that the way in which a society relates to its past is a complex phenomenon, and that political uses of archaeology in the western Balkans cannot be associated entirely with Socialist regimes and Communist ideologies. It is argued that different uses of archaeology are the product of a complex interaction between the development of archaeological discipline and historical, social and cultural trajectories. Taking as starting point fascist archaeology enterprises in the Adriatic, this paper will discuss how multiple forms of 'usable past' (Brown \& Hamilakis 2003) are adopted in the construction of different types of identities. (MG)

\section{Regime Archaeology in Wartime}

Fascism broke away from the nineteenth century tradition in archaeology of seeing the state as cultural guardian. The regime usurped state monopoly in cultural policy, promoting archaeology as device of its propaganda and thus making it relevant for a broader public (Altekamp 2004: 69). Most of the Italian actions around the Mediterranean sea in the earliest part of the twentieth century were preceded by archaeological missions or by the establishment of cultural organizations abroad, which were clearly conceived as instruments of both domestic and foreign propaganda, as is shown in the words of the Italian ambassador in Turkey in 1922 (quoted in Barbanera 2013: 104):

\section{"Scientists and bumanists can be effective precursors of the most difficult and risky political solutions, preparing the ground under the alibi offered by the political intellectual ideals [...] However, the scope prepared for this purpose by men of letters and science is free and wide: it can go and lay a good foundation of political programs, where diplomacy and the use of armed forces have no access." 1}

\footnotetext{
1 "Gli scienziati ed i letterati possono essere validi precursori delle più difficili ed arrischiate soluzioni politiche, preparando il terreno sotto l'alibi offerto dalle idealità politiche dell'intelletto [... In In ogni caso la sfera d'azione organizzata a tale fine dagli uomini di lettere e di scienze ha un campo libero e vasto: essa può spingersi e gettare buone fondamenta di programmi politici laddove la diplomazia e l'impiego della forza armata non banno accesso" (translation from Italian EC).
} 
Few years later, in 1929, the Museo dell'Impero Romano in Rome was founded as a permanent celebration of Roman colonial achievements. Luigi Maria Ugolini, at the time an ambitious, young archaeologist, was chosen as a 'malleable instrument' for a strategic mission in Albania (Petricioli 1986: 29; Magnani 2007: 32; Pessina \& Vella 2015: 32; Tagliamonte 2015). The political aim, amongst others, of the archaeological mission was to create a common Italian and Albanian past in order to justify the imperial expansion of fascist Italy in the eastern Mediterranean. Indeed, the archaeological exploration of Albania was planned for two main reasons: firstly, to bring back to light the Illyrian roots of the Albanians, mainly as confirmation of the cultural autonomy of Albanians in respect to their Slavic neighbours; secondly, to show, with this action, that the fascist government was taking care of its ally as direct descendants of ancient Illyrians (Buora 2007: Šašel Kos 2007). Some years earlier in 1926, the Italian mission at Phoenike was established with the clear intent of opposing the French archaeological and diplomatic mission (Barbanera 1998: 128-129; Magnani 2007: 33; Pessina \&Vella 2015: 396). Between 1927 and 1928 the necessity of proving the existence of an ancient connection between Italy and Albania underlaid a further expedition to Butrint: the site was believed to be a Trojan settlement founded by Helenus and Andromache and visited by Aeneas, the mythical ancestor of the Romans. This provided an excellent justification for intensifying Italian control over the southern Albanian coastline, and, in 1928, Ugolini moved to the Examili peninsula in his quest for Parvam Ilium (Magnani 1996: 58). The intuition and methods of Ugolini were rewarded: uncovering a wide and imposing ancient city, he investigated the later remains up to Venetian occupation levels, and, unexpectedly, he uncovered the remains of phases preceding the Illyrian period. Below the fourth century BCE levels, Ugolini reached pre-historic deposits (Magnani 2007: 42) portraying close connections between Albania and Southern Italy, as territories both occupied by the socalled 'Adriatic civilization' (Ugolini 1928; Magnani 2007: 42; Pessina \& Vella 2014: 397). The identification of a common Adriatic background was ready to be offered to the fascist propaganda machine. The outstanding scientific results reached by Ugolini were utilized by the fascist regime and at the same time gave scientific credibility to the Italian enterprise at international level (Gilkes \& Skeates 2005: 1-2). After Ugolini's unexpected death, the real intentions of Italian regime became evident with the 1939-1943 occupation.

On 28 October 1940, the Greco-Italian war began with the invasion of Greece by the Italian forces. This marked the beginning of the Balkans campaign of the Second World War. During the next three years Yugoslavia, continental Greece and Crete were occu-

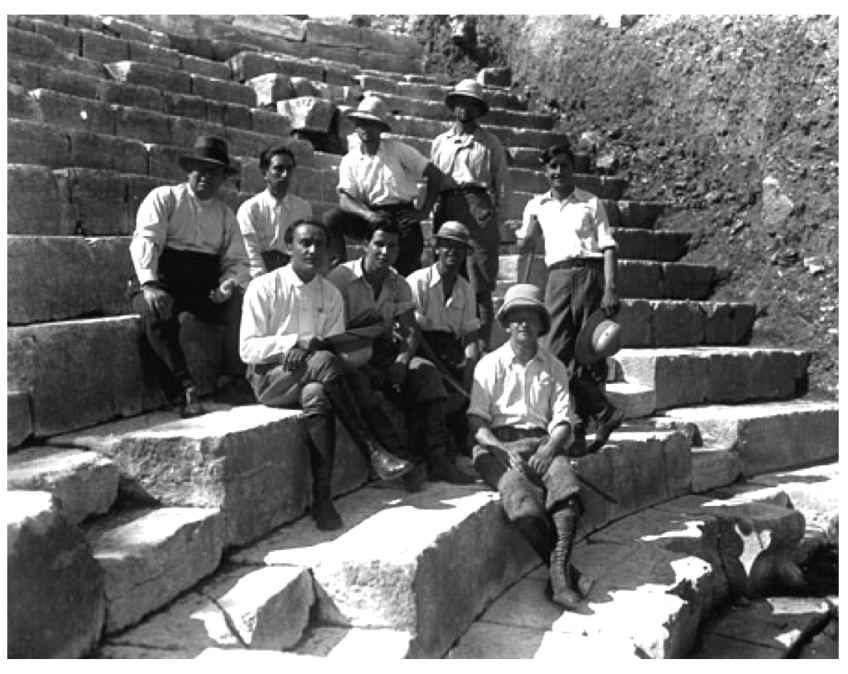

Figure 1. Ugolini (bottom) and the Italian Archaeological Mission at Butrint (photograph courtesy of Richard Hodges). 
pied by the Axis powers. Different archaeological missions, promoted on the other side of the Adriatic by the fascist regime in the preceding years, proved to be a very effective means by which to increase control of both the sides of Otranto Channel, and to strengthen economic control over the Balkans (Borgogni 2007).

Italy obtained Trieste, Istria and Zara at the end of the First World War and during the Second World War it occupied Dalmatia and Split. The fascist regime attempted cultural penetration in Yugoslavia, especially in Croatia, mostly through Italian Institutes of Culture that were established in the most important cities such as Zagreb, Sarajevo, Banja Luka, Mostar, and Dubrovnik (Rodogno 2006: 222). Naturally, the outstanding Roman remains in Dalmatia were targeted by fascist cultural policy to propagate the ideals of Romanità, Italianità and Venezianità (Brock 2007: 174). Until 1941 the preservation of Zara's monuments was assigned to the Soprintendenza d'Ancona. During the occupation, the city was the seat of the Regio Commissario per le Antichità, i Monumenti e le Gallerie della Dalmazia, which was directly dependent on the Ministry of National Education. Diocletian's palace in Split was the target of a mission organized by the regime with the aim of planning its restoration to enhance fascist ideals (Brock 2007). Italian cultural policy in Dalmatia targeted mainly the restoration of ancient monuments rather than initiating new excavations.

In contrast to Albania, in Yugoslavia archaeology as a scientific discipline had been established earlier, whilst the area was still under the domination of the AustroHungarian Empire. In the nineteenth century, regional museums and scientific journals were established in several cities (Wilkes 1992: 8-9), and the so-called German School of archaeology (Novaković 2012) shaped and directed the discipline's establishment from its very beginning. Indeed, most of the archaeologists working in the western Balkans obtained their degrees at Austro-Hungarian universities and the German School and its cultural-historical approach deeply influenced archaeology in the whole western Balkans, even during the ensuing Cold War period. (EC)

\section{The Cold War Era}

Following the Second World War the Adriatic geopolitical pattern changed substantially with the creation of a watershed dividing the west from the eastern bloc. In the countries under the Warsaw Pact - but also in Yugoslavia, which was member of the Non-Aligned Movement - archaeology was strongly influenced by Marxist and Soviet approaches, which promoted a materialistic understanding of human history in accordance with the guiding philosophy of the ruling Communist and Socialist Parties (Trigger 1989). Despite being under direct Soviet political influence for only a short period of time, Albanian archaeology was influenced by the Soviet approach since several archaeological excavations were carried out jointly by the two states. Marxist and Soviet approaches to archaeology were assimilated by both the Albanian and the Yugoslav Academy of Sciences and, combined with local scientific backgrounds, which were, in turn, permeated by the cultural-historical approach to material culture.

After the end of the Second World War, Enver Hoxha seized power and dismissed every foreign archaeological mission from Albania. From this moment onwards, until the fall of the communist regime, the country became increasingly isolated from the 
rest of the world. The legacy of Italian fascist archaeology was retained in the enduring cultural-historical approach with its strong emphasis on autochthony, which lies at the foundation of the archaeological discourse underlying national identity construction (Wilkes 1992: 10). It is undoubtedly true that, during the Cold War period, the Albanian regime adopted the fascist use of archaeology as a vehicle of propaganda, but this time for the Communist Party.

Several archaeological campaigns were launched to identify the Illyrian roots of the Albanian nation. The Academy of Sciences of Albania was established in 1972, and through this institution the regime directed and shaped Albanian archaeology. Hoxha's propaganda machine merged archaeology with linguistics and ethnology to form one subject: Albanology. Different disciplines were to work together to construct the identity of present-day Albanian people as direct descendants from ancient Illyrians. The ethnogenetic process was believed to have started already in prehistoric times (EC).

One of the salient characteristics linking the Illyrian and Albanian nations in the archaeological discourse, which lies at the heart of national identity building, was the continuous and strenuous defence of the independence of the Illyrian territory against its neighbours, identified as present-day Slavs and Greeks. Present territorial issues with Yugoslavia and

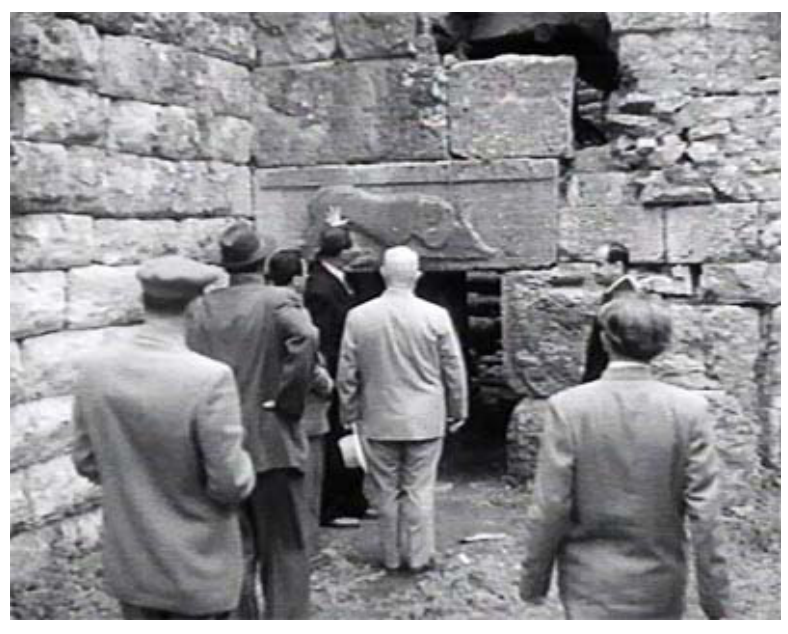

Figure 2. Nikita Khrushchev, Enver Hoxha and Nexhmije Hoxha visiting Butrint in 1959.
Greece were thus projected back into a far remote past (see e.g. Pollo \& Pluto 1981).

The socialist Yugoslav regime supported and promoted archaeology as an important instrument for the emancipation of the Yugoslav nations, which was seen as a more important task than insisting on 'class-struggle' types of interpretations of the archaeological record. Dzino underlines how the influence and impact of Marxist ideology in Yugoslavia is best visible through the terminology that was used

for describing social relations in Illyrian societies. "Primitive communities, tribal aristocracy, emerging class division" are expressions that are often found in Yugoslav archaeological literature of the period (Dzino 2008: 44). In this political framework the Illyrians were regarded as a macro-ethnic group made up of heterogeneous and culturally loosely linked tribes that inhabited Roman Illyricum, whose unification into a single ethnos was prevented by the Roman occupation completed in the early first century CE. The parallel with a socialist federal Yugoslavia, pervaded by brotherhood-and-unity ideology, made up of different but kin nations bound by a joint political structure, was projected into the Illyrian past (Dzino 2008: 45). The idea of a general Illyrian identity as the foundation for Yugoslavian identity was 
undermined by socio-political changes. Local identities became more relevant and archaeological research started to place more emphasis on local groups and local identities, such as Liburnians and Dalmatians. In this way local national identities entered into the archaeological discourse, to the detriment of the Yugoslav one. Ethnic issues based on archaeology, but reflecting the political tensions between Albania and Yugoslavia, were a prelude to the Yugoslav wars and they were addressed within academia. Archaeology was used either to substantiate or to contrast the political claims that would ultimately lead to the Yugoslav wars. This can clearly be seen in the conferences organised by Albanian and Yugoslavian Academies of Science, which focused on the relation between the Illyrians and the Albanians (Gori 2012: 78-79). Conflicts and inter-ethnic tensions, such as the Serbian-Albanian clash over Kosovo, were projected into the past through the debate over the ethnic origins of the populations who dwelled in antiquity in the areas presently inhabited by ethnic Albanians. (MG)

\section{The Sunset of Communism}

In Yugoslavia, the use of archaeological discourse, in order to substantiate nationalistic claims, increased in importance when Yugoslav ideology disintegrated. The decentralised constitution of 1974 favoured the rising of nationalism in the 1980 s, which resulted in a bloody war that destroyed the socialist federation in the 1990s. Following the disappearance of the socialist regime, archaeology continued to be extensively used as a political tool in support of nationalistic claims. During the armed conflict for control over Kosovo (1996-1999), Serbia, through its Academy of Sciences, played again the card of archaeology to reaffirm its dominion over the region. The exhibition Archaeological Treasures of Kosovo and Metohija. From Prehistory to the Middle Ages was organized by the Serbian Academy of Science in 1998. Dardanians and Illyrians occupied a central place in the catalogue's chapters devoted to the Iron Age. Dardanians are identified as an independent people of Daco-Mysian origin, whose Bronze Age substratum can be identified in the Brnjica-Strazava culture. The Brnjica culture is described as an archaeological group in present-day Serbia dating from $1400 \mathrm{BCE}$, which is identified as the non-Illyrian component in the Dardanian ethnogenesis ('Tasić 1998).

In Albania, following the fall of the communist regime, the old ethnogenetic approach to material culture that characterized archaeological research during Hoxha's dictatorship remained in use. For example, Neritan Ceka, a politician and archaeologist still focuses in his 2005 work on the ethnogenetic relationship between Illyrians and present-day Albanians: The Illyrians to the Albanians (Ceka 2005) is, more than a title, an ideological manifesto. However, the fall of communism opened Albanian archaeology to the international academia, and the Albanian Academy of Science decisively distanced itself from the ethnogenetic approach. The equation Illyrians-Albanians is nowadays mainly present at a popular level of archaeological discourse. (MG) 


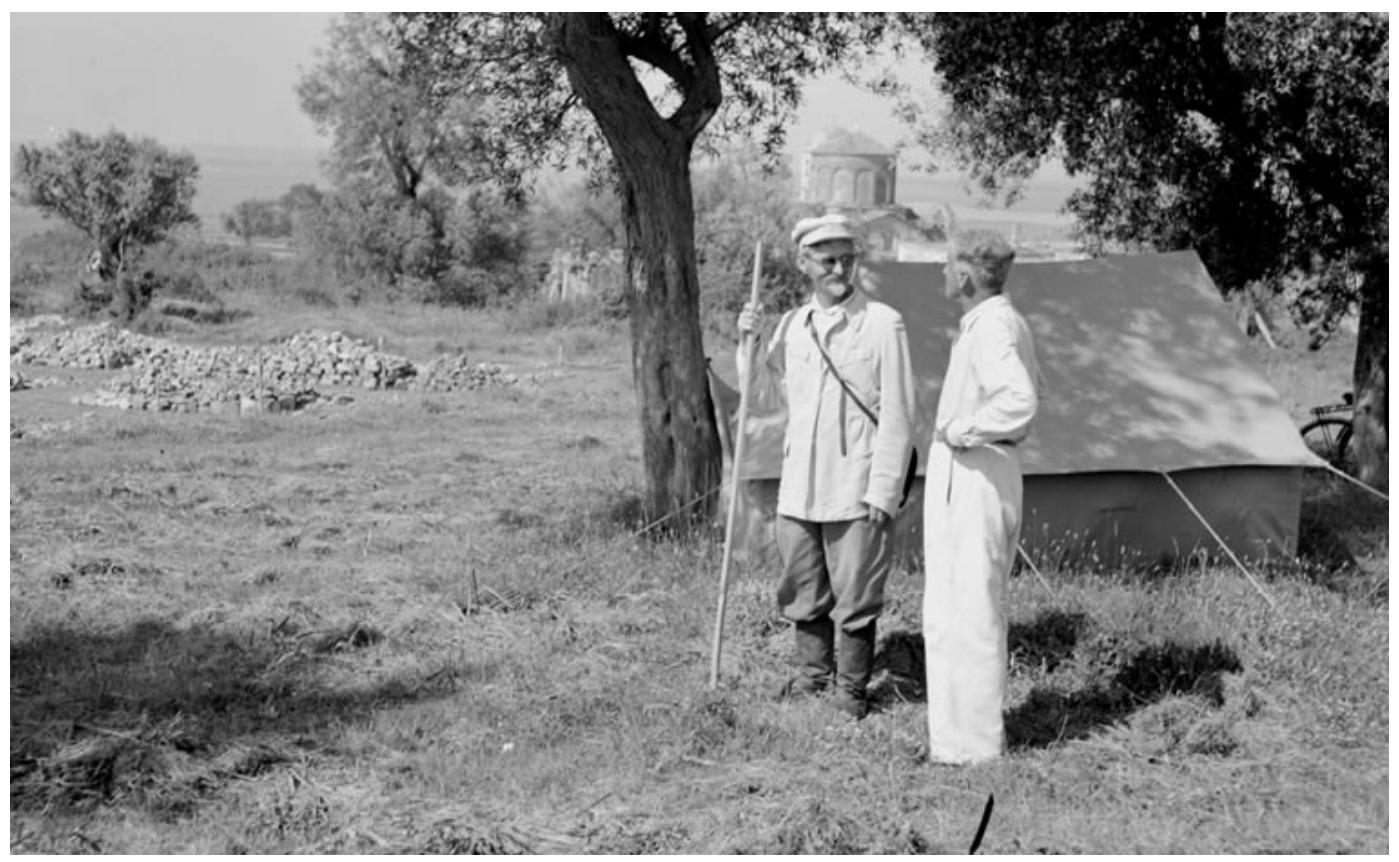

Figure 3. Vladimir Demitriović Blavatski and Hasan Ceka in Apollonia, 1958.

\section{Concluding Thoughts}

In the western Balkans the use of archaeology for building national identity mirrors the profound influence that nineteenth century European archaeology had in establishing archaeology as an academic subject in the region. In both Albania and the former Yugoslavia, the projection of present-day national entities and identities back into a remote past cannot be simplistically regarded as the manipulation of the archaeological record or its distortion for political means. It is true that archaeology was deeply exploited in ethno-nationalistic debates, which were commonly the basis of claims for self-determination, separatism and expansion. Demand for national independence or territorial expansion often involved the assertion of the right of sovereignty on the basis of ethno-linguistic distinctiveness and historical precedence over a given territory. However, the approach to the past in use in Albania and former Yugoslavia was deeply influenced by central European trends in archaeological interpretation, which were framed in different local, cultural, social and political contexts. Recent research has put emphasis on a political use of archaeology that does not necessarily imply nationalism, proving that the relationship between archaeology and politics is not always straightforward (Luke \& Kersel 2013; Niklasson \& Meier 2013). The way in which a society relates to its past is a more complex phenomenon, where different agents and power balances are involved, both at a domestic and an international level. The brief history of archaeology's development presented in this paper has shown how the political use of archaeology in the western Balkans cannot be associated entirely with Socialist regimes and Communist ideologies. Instead, we interpret it as a local development of the European tendencies in archaeological interpretation. Furthermore, the fall of communism impacted differently on Albania and Yugoslavia. In Albania 
the fall of Hoxha's regime functioned as a trigger to transform interpretative frameworks abandoning cultural-historical and ethnogenetic approaches. At a popular level, the equation Illyrians-Albanians is still alive, while at a scientific level, this correspondence is questioned. In Yugoslavia, on the contrary, the fall of communism was one of the causes of a violent, armed conflict in which the destruction and manipulation of the past played a fundamental role. Today, the use of archaeology to substantiate political claims is still evident in several of the former Yugoslav republics, in which different approaches to archaeology, in some cases nationalist-oriented, in others focusing more on tourism, coexist with the scientific approach of universities and research institutions. (EC/MG/AP)

\section{References}

AlteKAmp, S., 2004. Italian colonial archaeology in Libya 1912-1942, in: M.L. GALATY \& C. WATKINSON (eds.), Archaeology under Dictatorship. New York: Kluwer Academic/Plenum Publ., 55-71.

BARBANERA M., 1998. L'archeologia degli Italiani. Roma: Editori riuniti.

Barbanera M., 2013. Archeologia e politica durante il fascismo, in: M. Barbanera, Il museo impossibile. Roma: Aracne editrice, 87-120.

Borgogni, M., 2007. Tra continuità e incertezza. Italia e Albania (1914-1939). La strategia politico-militare in Albania fino all'operazione "Oltre Mare Tirana». Milano: Franco Angeli.

Brock I. 2007. Spalato Romana. La missione della Reale Accademia d'Italia a Spalato 29. 9. - 3. 10. 1941. Baśtina 34: 173-228.

Brown K.S. \& Y. Hamilakis (eds.), 2003. The Usable Past. Greek Metahistories. Lanham: Lexington Books.

Buora, M. 2007. Etnogenetica balcanica. Veneti e Illiri nella storiografia italiana tra Ottocento e Novecento, in: S. Magnani, \& C. Marcaccini (eds.), Le identità difficili: archeologia, potere, propaganda nei Balcani. Portolano Adriatico, Rivista di storia e cultura balcanica III.3: 19-30.

CEKA, N., 2005. The Illyrians to the Albanians. Tirana: Migjeni.

Diaz-Andreu M. \& T. Champion (eds.), 1996. Nationalism and Archaeology in Europe. London: UCL press.

Dzino, D., 2008. Deconstructing 'Illyrians': Zeitgeist, Changing Perceptions and the Identity of peoples from ancient Illyricum. Croatian Studies Review 5: 43-55.

Galaty, M.L. \& C. Watkinson (eds.), 2004. Archaeology under Dictatorship. New York: Kluwer Academic/Plenum Publ.

O. GILKES \& R. SKEATES, 2005. An introduction to Luigi Cardini and the Italian Archaeological Mission, in: K. FAnCIS (ed.), Exploration in Albania. Athens: BSA 2005, 1-9.

Gori M., 2012. Who are the Illyrians? The Use and Abuse of Archaeology in the Construction of National and Trans-National Identities in the Southwestern Balkans, in: C. N. Popa \& R. Ó RíagÁin (eds.), Archaeology and the (De) Construction of National and Supra-National Polities. Archaeological Review from Cambridge 27.2: 71-84.

Graves-Brown P., S. Jones \& C. Gamble (eds.), 1996. Cultural Identity and Archaeology. The Construction of European Communities. London, New York: Routledge. 
Hamilakis, Y., 1996. Through the looking glass: nationalism, archaeology and the politics of identity. Antiquity 60: 975-978.

Hoвsваум E., 1977. Some Reflections on “The Break-up of Britain”. New Left Review 105: 3-23. Hodder, I. (ed.), 1991. Archaeological Theory in Europe. The Last Three Decades. London and New York: Routledge.

Hodder, I. \& S. Hutson, 2003. Reading the Past: Current Approaches to Interpretation in Archaeology. Cambridge: Cambridge University Press.

Kaiser, T., 1995. Archaeology and ideology in southeast Europe, in: P. KoHL \& C. FawCett (eds.), Nationalism, Politics, and the Practice of Archaeology. Cambridge: Cambridge University Press, 99-119.

Kohl, P., \& C. Fawcett (eds.), 1995. Nationalism, Politics and the Practice of Archaeology. Cambridge: Cambridge University Press.

Luke, C. \& M. M. Kersel, 2013. U.S. Cultural Diplomacy and Archaeology. Soft Power, Hard Heritage. New York: Routledge.

Magnani, S., 1996. Butrinto, Virgilio e l'immaginario antico, in: L'archeologo scopre la storia 1996. Luigi M. Ugolini (1895-1936), Giornata Internazionale di Studi. Quaderni Bertinoresi 6. Bertinoro: 59-71.

Magnani, S., 2007. In Albania sulle orme di Roma. L'archeologia politica di Luigi Maria Ugolini, in: S. Magnani, \& C. Marcaccini (eds.), Le identità difficili: archeologia, potere, propaganda nei Balcani. Portolano Adriatico, Rivista di storia e cultura balcanica III.3: 31-46.

Meskeld, L. (ed.), 1998. Archaeology Under Fire. Nationalism, Politics and Heritage in the Eastern Mediterranean and Middle East. London: Routledge.

Niklasson, E., \& T. Meier (eds.), 2013. Appropriate narratives. Archaeologists, publics and stories. Budapest: Archaeolingua Alapítvány.

Novaković, P., 2012. The "German School" and its influence on the national archaeologies of the Western Balkans, in: B. Migotti, P. Mason, B. Nadbath \& T. Muhl (eds.), Scripta in honorem Bojan Djurić. Lubiana: Zavod za varstvo culture red. Slo., 51-71.

Pessina, A., \& N. C. Vella, 2015. Archeologia e Fascismo negli archivi di Luigi Maria Ugolini, in: A. GuIDI (ed.), 150 anni di preistoria e protostoria in Italia, Atti della XLVI Riunione Scientifica IIPP, Roma, 395-404.

Petricioli, M. 1986. Le missioni archeologiche italiane nei paesi del Mediterraneo: uno strumento di politica internazionale, in: V. LA Rosa (ed.), L'archeologia italiana nel Mediterraneo, Catania, 9-31.

Pollo, S. \& A. Pluto, 1981. The History of Albania from its Origins to Present Day. London: Routledge.

Rodogno, D., 2006. Fascism's European Empire: Italian Occupation during the Second World War. Cambridge: Cambridge University Press.

ŠAŠEL KoS, M. 2007. Ethnic manipulations with ancient Veneti and Illyrians, in: S. Magnani, \& C. Marcaccini (eds.), Le identità difficili: archeologia, potere, propaganda nei Balcani. Portolano Adriatico, Rivista di storia e cultura balcanica III.3: 11-18.

Tagliamonte, G. (ed.), 2015. Ricerche archeologiche in Albania. Atti dell'Incontro di studi, Cavallino-Lecce, 29-30 aprile 2011. Roma: Aracne editrice.

TAsić, N. (ed.), 1998. Arheološko blago Kosova i Metohije: od neolita do ranog srednjeg veka. Beograd: Srpska Akademija Nauka i Umetnosti. 
Trigger, B.G., 1989. A history of archaeological thought. Cambridge: Cambridge University Press. Ugolini, L.M., 1928. L'antica Albania nelle ricerche archeologiche italiane. Roma: Ente nazionale Industrie turistiche.

WILKES, J., 1992. The Illyrians. Oxford: Blackwell. 